\title{
Surface Ozone Monitoring and Background Concentration at Zhongshan Station, Antarctica
}

\author{
Lingen Bian ${ }^{1,2}$, Lei Ye², Minghu Ding1, Zhiqiu Gao², Xiangdong Zheng1, Russell C. Schnell³ \\ ${ }^{1}$ Chinese Academy of Meteorological Sciences, Beijing, China \\ ${ }^{2}$ Climate and Weather Disasters Collaborative Innovation Center, Nanjing University of Information Science \& Technology, \\ Nanjing, China \\ ${ }^{3}$ NOAA ESRL Global Monitoring Division, R/GMD, Boulder, USA \\ Email: blg@camscma.cn; zgao@nuist.edu.cn
}

How to cite this paper: Bian, L.G., Ye, L., Ding, M.H., Gao, Z.Q., Zheng, X.D. and Schnell, R.C. (2018) Surface Ozone Monitoring and Background Concentration at Zhongshan Station, Antarctica. Atmospheric and Climate Sciences, 8, 1-14. https://doi.org/10.4236/acs.2018.81001

Received: July 16, 2017

Accepted: December 30, 2017

Published: January 2, 2018

Copyright $\odot 2018$ by authors and Scientific Research Publishing Inc. This work is licensed under the Creative Commons Attribution International License (CC BY 4.0).

http://creativecommons.org/licenses/by/4.0/ Open Access

\begin{abstract}
The background surface $\mathrm{O}_{3}$ concentrations and seasonal changes observed at the Zhongshan Station $\left(69^{\circ} 22^{\prime} 2^{\prime \prime} S, 76^{\circ} 21^{\prime} 49^{\prime \prime E} ; 18.5 \mathrm{~m}\right.$ ), east Antarctica from 2008 to 2013 are presented. Irrespective of wind direction, surface $\mathrm{O}_{3}$ concentrations distribute evenly after the removal of polluted air from station operations, accounting for $1.1 \%$ of the data. These $\mathrm{O}_{3}$ exhibit the expected lowest in summer, with a peak in winter. The daily range of average $\mathrm{O}_{3}$ in all four seasons is small. The monthly mean $\mathrm{O}_{3}$ is similar to that of other stations in Antarctica, with seasonal $\mathrm{CO}_{2}$ amplitudes in the order of $15 \mathrm{ppb}$ to $35 \mathrm{ppb}$. Surface $\mathrm{O}_{3}$ significantly negatively correlated with UVB in the spring and autumn, with correlation coefficients of 0.50 and 0.57 under the 0.01 significance test. Furthermore, the surface $\mathrm{O}_{3}$ concentration during polar nights was 1 - 2 times higher than that during polar days. Thus, the chemical effect of the aurora lights was the dominant cause of ozone destruction, showing that surface $\mathrm{O}_{3}$ observed in Antarctica has a small interferences from human activities in the atmosphere as it moves from the north through the southern hemisphere.
\end{abstract}

\section{Keywords}

Antarctica, Zhongshan Station, Surface Ozone, Background Concentration

\section{Introduction}

The troposphere ozone has two major sources: the photochemical production of the troposphere and transport of the stratosphere. The photochemical source of the troposphere ozone is mainly controlled by the emission of ozone precursors, 
including $\mathrm{NO}_{\mathrm{x}}$ and volatile organic compounds (VOCs). The majority of surface ozone growth might be related to increased precursor emissions before photochemical reaction. Since the industrial age, the troposphere ozone concentration has at least doubled [1]. In polar region, which lack human-induced sources, especially in Antarctic region, the troposphere ozone is mainly determined by natural processes, namely, the meridional transport of airflow and downward transport of the stratosphere. Therefore, surface ozone data in polar region contain important values for evaluating ozone variation trend. The longest ozone observation data of Arctic region is in Barrow station. The annual growth trend was found to be $0.05 \pm 0.08$ ppbv. By contrast, the longest ozone observation data in Antarctic region is in South Pole station, and annual growth trend was 0.02 $\pm 0.09 \mathrm{ppbv}$. The growth trends in both stations are insignificantly different [2]. The surface ozone concentration in Antarctic region shows evident seasonal changes, reaching the highest in winter and the lowest in summer [3]. This variation is due to clean atmospheric environment and unique geographic location of the Antarctic region. The ozone is generally accumulated in winter and destroyed by photochemical process in spring and summer [4]. In addition, the unique climatic feature and atmospheric boundary structure of Antarctic region render chemical process of ozone complicated [5]. In coastal areas of Antarctic region, the surface ozone concentration drops sharply in winter and spring and even occasionally decreases to detection limit of the instrument [6]. In 1980s, Alaska Barrow Station [7] and Alert Station in northern Canada appeared a course of event called sharp reduction of ozone concentration as an ozone depletion episode (ODE) [8]. In the 1990s, reported ODEs in Antarctic region [9] [10]. Given an analysis of historical ozone data in Antarctic region, Roscoe [11] pointed out that an ODE was recorded by Halley Station in 1958. Studies have reported that ODE is mainly driven by halogen chemistry and related to discharge active bromine in sea ice areas [12]).

In Antarctic South Pole Station and Concordia Station, elight-denitrification of snows can influence ozone concentration in atmospheric boundary layer during spring and summer [13] [14]. Such denitrification could cause nitrate that has settled in snows to release $\mathrm{NO}_{\mathrm{x}}$. In summer, strong solar radiation can convert $\mathrm{NO}_{\mathrm{x}}$ quickly through photochemical process. Consequently, a small growth of ozone concentration is achieved [15] [16]. The local ozone production might be related to environmental pollution.

When Antarctic ozone hole (AOH) appears, the amount of UVB that reaches earth's surface increases slightly at the hole. Therefore, photochemical process increases and surface ozone drops significantly. Jones and Wolff [17] proposed that ozone hole in stratosphere in 1980s increased the NOx released by snows at boundary layer and surface ozone photochemical production in South Pole Station. According to this hypothesis, slow recovery of the stratosphere ozone in Antarctic region is expected to lead to a low surface ozone production rate in Antarctic Plateau. Polar region are located far away from other continents and 
experience smallest interferences from human activities. With support of China's Action Plan in the Fourth International Polar Year (2008/2009), the Antarctic Zhongshan atmospheric monitoring station was established. Both continuous in situ and weekly flask sample measurements of greenhouse gases are part of research program at the station and of continuous meteorological observations [18] [19] [20]. In this paper, we analyzed the surface $\mathrm{O}_{3}$ data from 2008 to 2013 at Zhongshan for the concentrations, seasonality, and trends and their relations to meteorological factors. The variation characteristics of surface $\mathrm{O}_{3}$ in Zhongshan data were compared with those of other Antarctic Stations obtained through World Data Center for Greenhouse Gases (WDCGG) of WMO.

\section{Observation}

\subsection{Observation Site}

Zhongshan Station is located at the Larsemann Hills of Prydz Bay of the east Antarctic continent. Meanwhile, the atmospheric composition monitoring site is situated on highest hills at northwest edge of the station, specifically, flat bare rock at top of Tiane Range $\left(69^{\circ} 22^{\prime} 12^{\prime \prime} \mathrm{S}, 76^{\circ} 21^{\prime} 49^{\prime \prime} \mathrm{E}, 18.5 \mathrm{~m}\right)$. This site is next to ocean in west and north directions and next to ice-covered areas in east and south (Figure 1). There are 54 polar days and 58 polar nights at the station. Northern east wind prevails throughout the year with an average wind speed of $7.5 \mathrm{~m} / \mathrm{s}$. Gale wind (>8 scale) lasts for 174 days, and the extreme wind speed has reached $43.6 \mathrm{~m} / \mathrm{s}$. The annual mean temperature is below $-10^{\circ} \mathrm{C}$. The minimum and the maximum temperature were $-44^{\circ} \mathrm{C}$ and $10^{\circ} \mathrm{C}$, respectively, at the station from 1989 to 2013.

\subsection{Observation Instrument}

An EC9810A ozone analyzer and an EC 9811 ozone calibrator (ECO tech) have

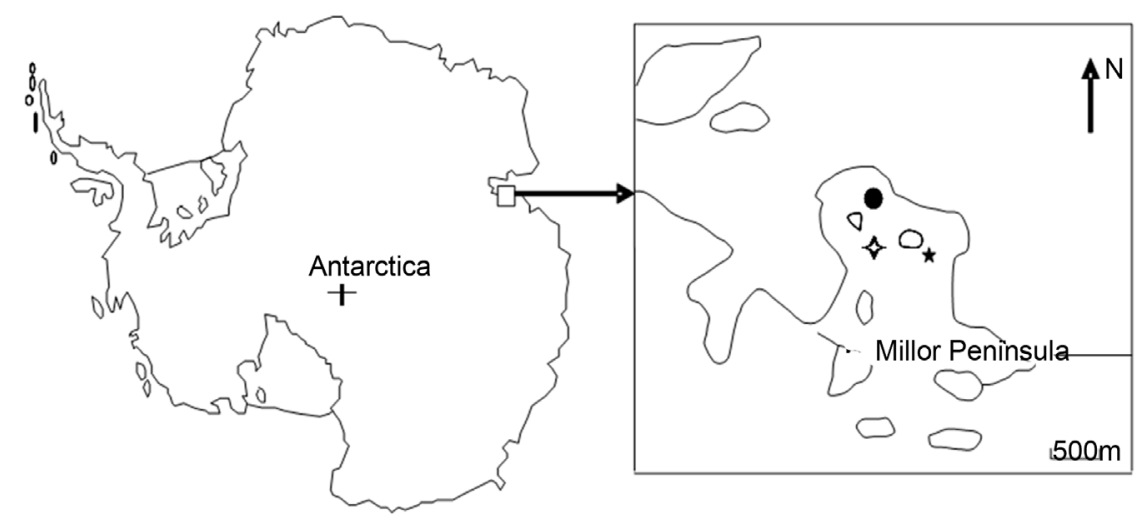

- Observation site of Ozone Concentration
$\diamond$ Zhongshan Station
$\star$ Progress Station

Figure 1. Study area (a) and locations of the monitoring site for surface ozone concentrations at the Zhongshan Station (b). 
been used for surface ozone measurement with data storage system from January 2008 to December 2013. The sampling frequency was $3 \mathrm{~min}$ and calibration every 3 months by five standard ozone samples. In data processing, the data during machine failure and instrument maintenance were deleted from the duty records. UVB data were derived from the observation data of the Brewer ozone spectrophotometer on the total ozone and UVB levels at Zhongshan Station. The measured UVB refers to the UV radiation that reaches ground level. The wavelength, scanning interval, and integral time were set as $295-325 \mathrm{~nm}, 0.5 \mathrm{~nm}$, and $0.224 \mathrm{~s}$, respectively.

\subsection{Data Treatment}

Peak and uncommon data were deleted by variance test on the basis of the criteria of $\left|x_{i}-\bar{x}\right|>3 \sigma$, where $x_{i}$ is measured data, $\bar{x}$ is time series mean, and $\sigma$ is standard deviation [18] [19]. While calculating hourly mean, the hourly means smaller than two data groups were not included and viewed as missing. The processed monthly sample size of hourly average surface ozone concentrations in Zhongshan Station is shown in Figure 2. Except for relatively small data size in January and February 2010 due to missing data, overall data integrity was relatively high and reached 91\%. All statistical analyses were performed with SPSS statistics 17.0 and Microsoft Excel for Windows 2007 [20]. The surface ozone data from other Antarctic stations were collected from WDCGG of WMO (http://gaw.kishou.go.jp/cgi-bin/wdcgg/).

\section{Wind Influence on Surface Ozone Concentration}

The influences of emissions from Station are not being eliminated completely through above-mentioned data processing. Surface wind is an important factor influencing observed data [21]. Extracting observation data of atmosphere background that has not been influenced by local factors is basis for discussing background characteristics of surface ozone levels and source influences. To eliminate possible effects on surface ozone concentration exerted by local sources operations from Zhongshan Station and Russia Station, we drawn a rose diagram on basis of 16 wind directions data at Zhongshan Station. We also counted wind

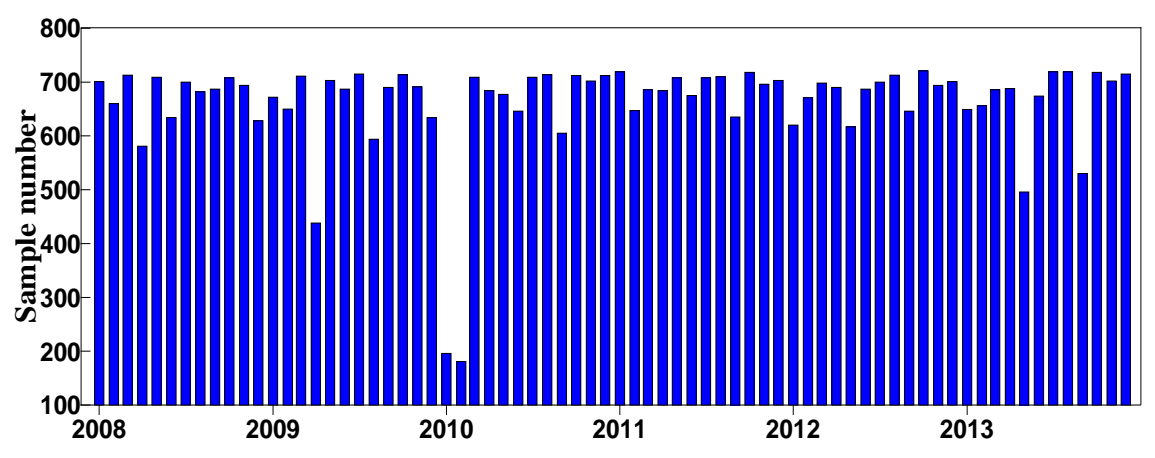

Figure 2. Monthly samples of hourly average surface ozone concentrations at the Zhongshan Station from 2008 to 2013. 
frequency (WFs) of different wind directions and corresponding average wind speeds and surface ozone concentrations. The WFs, average wind speeds (WSs), and average surface ozone concentrations at 16 wind directions recorded by Zhongshan Station from 2008 to 2013 are shown in Figure 3. Obviously, ENE prevailed throughout the year. The WF of the ENE, E, and ESE directions was $72.1 \%$. This value indicates that atmospheric composition observation site at Zhongshan Station was located at upstream airflow, and air mainly originated from Antarctic continental ice sheet and ocean at the east. Viewed from the wind directions, the average surface ozone concentration under the east wind was the highest $(27.3 \mathrm{ppb})$, followed by those under the west, ENE, and ESE winds, successively. The average surface ozone concentrations under the north and NNW winds were lowest (20.4 ppb), with values about $5 \mathrm{ppb}$ lower than those under the other wind directions. This observation may be due to relatively lower ozone content in air mass from the northern ocean. The power building and garbage incinerator of the Station are at southeast direction of the station and are about $400 \mathrm{~m}$ away from the observation site. These structures are the local sources that may chiefly influence the observation results. Figure 3 shows that the WF of the southeast wind is very small (about $2.2 \%$ ), and the average surface ozone concentration under the southeast wind is $23.8 \mathrm{ppb}$. This observation is basically similar to those under other wind directions. This finding reveals that observation results were not affected by human activities. However, the surface ozone concentration at Zhongshan Station was slightly influenced by wind direction. The concentrations remained basically stable under different wind directions.

WFs, WSs, and surface ozone concentrations under 16 wind directions in Figure 4 show that ENE wind prevails at Zhongshan Station in four seasons, but WF of NE wind increases slightly in summer. This change might be related to seasonal changes of general atmospheric circulation. WS distribution was similar to the annual distribution. The maximum WS occurred at the direction of

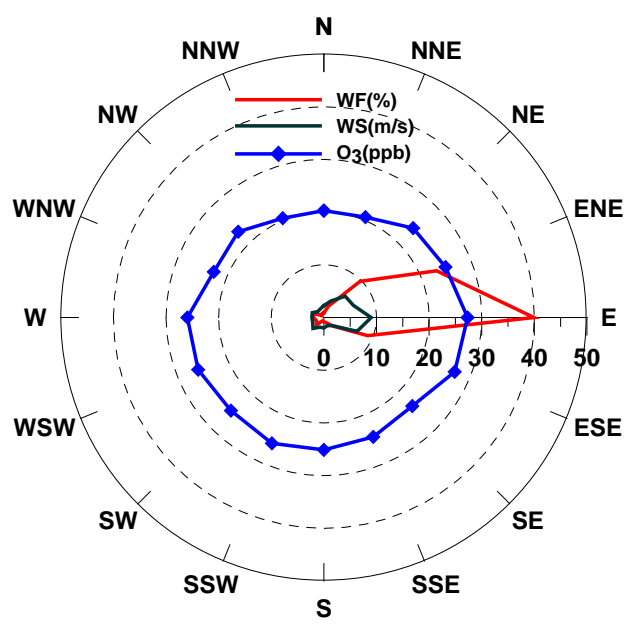

Figure 3. WFs, WSs, and average surface ozone concentrations at 16 wind directions recorded by the Zhongshan Station from 2008 to 2013. 


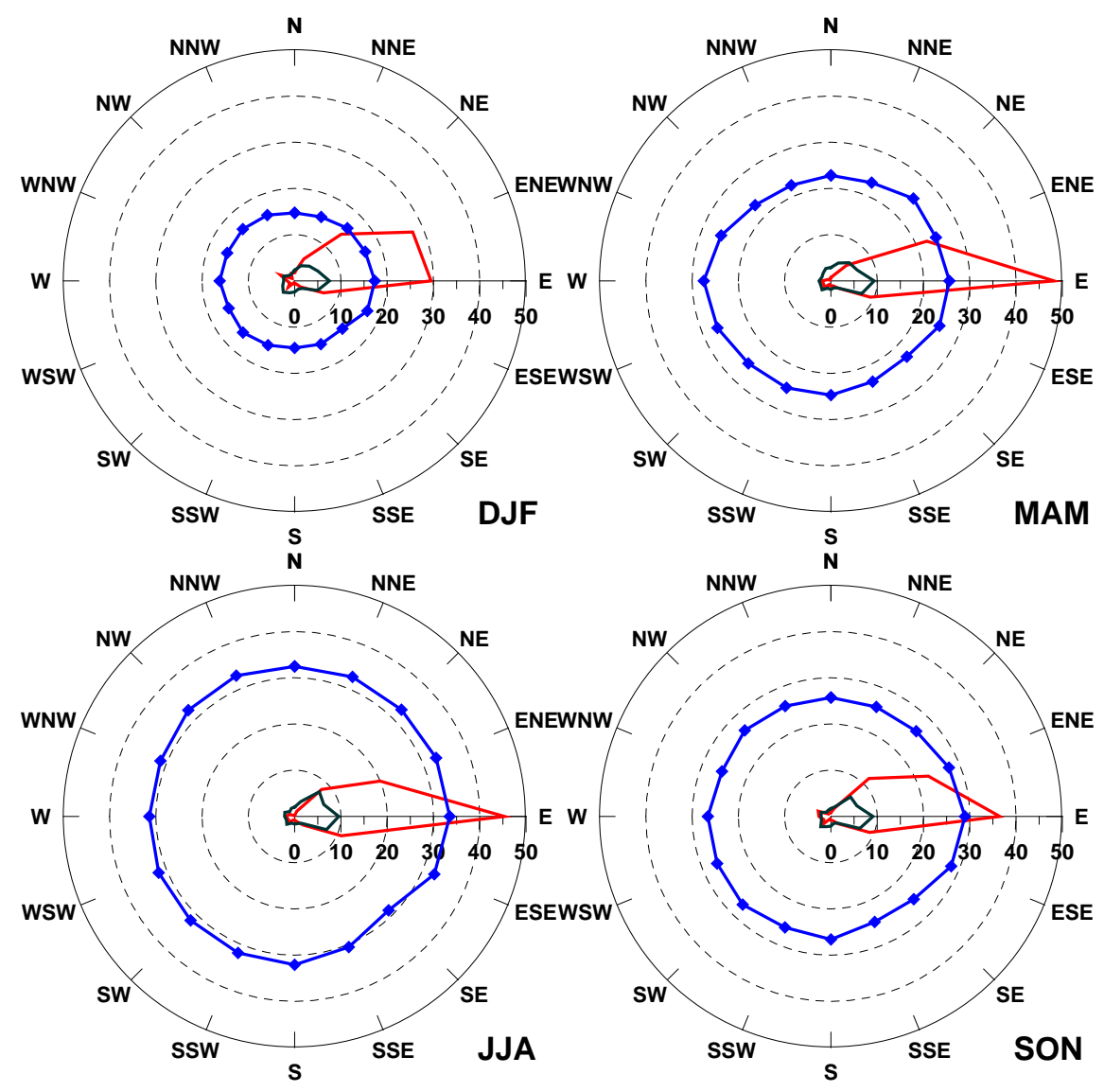

Figure 4. WFs, WSs, and average surface ozone concentrations at 16 wind directions recorded by the Zhongshan Station in summer (DJF), autumn (MAM), winter (JJA), and spring (SON) from 2008 to 2013.

maximum WF at ENE. Surface ozone concentrations in four seasons were almost similar. The average surface ozone concentrations under different wind directions across the four seasons demonstrated that surface ozone concentration is influenced unobvious by wind direction. Only surface ozone concentration under north wind in autumn was slightly lower than those under other wind directions. However, WF was very low $(<1 \%)$, which might be due to the small sample size.

The wind direction was unstable during lower WS that is unfavorable for pollutant diffusion, and the possible influencing ozone concentration must be considered (Zhou et al., 2004). WS from 2008 to 2013 was divided into seven groups $\left(<0.5 \mathrm{~m} \cdot \mathrm{s}^{-1}, 0.5-3 \mathrm{~m} \cdot \mathrm{s}^{-1}, 3-6 \mathrm{~m} \cdot \mathrm{s}^{-1}, 6-10 \mathrm{~m} \cdot \mathrm{s}^{-1}, 10-15 \mathrm{~m} \cdot \mathrm{s}^{-1}, 15-20 \mathrm{~m} \cdot \mathrm{s}^{-1}\right.$, and $>20 \mathrm{~m} \cdot \mathrm{s}^{-1}$ ) for statistical analysis. The occurrence frequencies of the different wind speed levels and corresponding surface ozone concentrations are shown in Figure 5. The wind speed mainly ranges from $0.5 \mathrm{~m} \cdot \mathrm{s}^{-1}$ to $15 \mathrm{~m} \cdot \mathrm{s}^{-1}$, accounting for $93.5 \%$ of the total samples. The WF at WSs higher than $20 \mathrm{~m} \cdot \mathrm{s}^{-1}$ was $0.8 \%$. The wind speed $\leq 0.5 \mathrm{~m} \cdot \mathrm{s}^{-1}$ is treated as static wind with occurrence frequency of $2.1 \%$. Surface ozone concentration and variation amplitude under different WSs were very close shown in Figure 5. This indicates the relatively uniform 


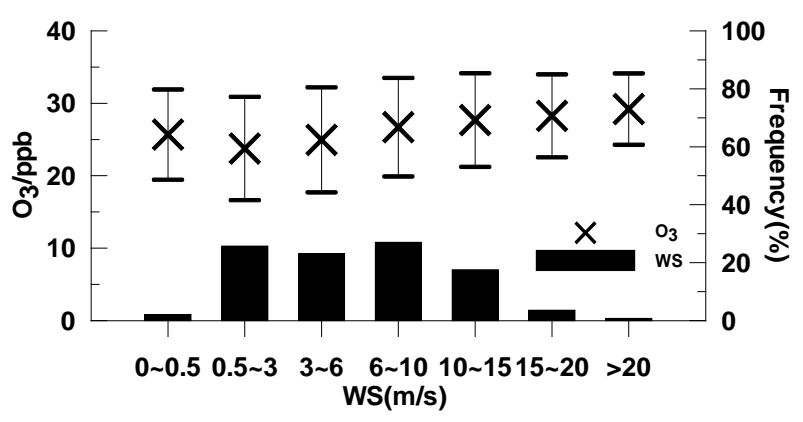

Figure 5. Occurrence frequency of different wind speed levels and the corresponding surface ozone concentrations from 2008 to 2013 (the black frame indicates the occurrence frequency of different wind speed levels and the vertical line is the variation range of the corresponding surface ozone concentrations).

distribution of the ozone concentration.

The variation amplitudes of surface ozone concentration with wind speed in four seasons are basically similar in Figure 6. When WS is small $\left(<3 \mathrm{~m} \cdot \mathrm{s}^{-1}\right)$ in winter, variation range of surface ozone concentration is relatively larger than those under other wind speed levels. This event might be related that the ODE in Antarctic coastal areas is often accompanied by lower wind speed. In addition, when the wind speed is $>20 \mathrm{~m} \cdot \mathrm{s}^{-1}$ in summer, variation range of surface ozone concentration is significantly higher than those under the other wind speed levels, this effect might be caused by limited samples. Hence, processed data of surface ozone without affect of local pollution from Station can represent background concentration.

\section{Seasonal Variation of Surface Ozone Background Concentration}

Average daily cycle of surface ozone concentration at Zhongshan Station in January (summer), April (autumn), July (winter), and October (spring) is illustrated respectively in Figure 7. The daily variation amplitudes of surface ozone concentrations in the four seasons were very litter, with values of $0.72,0.24,0.30$, and $0.83 \mathrm{ppb}$, respectively. Observation site is a bare rock region without vegetation in summer and it is covered by snow in other seasons. Hence, the region exerts no local impact on the observed surface ozone levels. The variations in ozone concentration were mainly related to large-scale atmospheric transport. This result further confirms that the monitored surface ozone concentration at Zhongshan Station can reflect changes in background concentration.

A time series of background surface ozone concentration processed by quality control is shown in Figure 8. The background surface ozone concentrations change stably and exhibit evident seasonal variations. This observation reflects the background characteristics of surface ozone concentrations at the Zhongshan Station. The highest surface ozone concentration is in the winter, and the lowest is in the summer. These findings reflect the accumulation process of surface ozone in winter and the photochemical process in other seasons [4] [14]. 


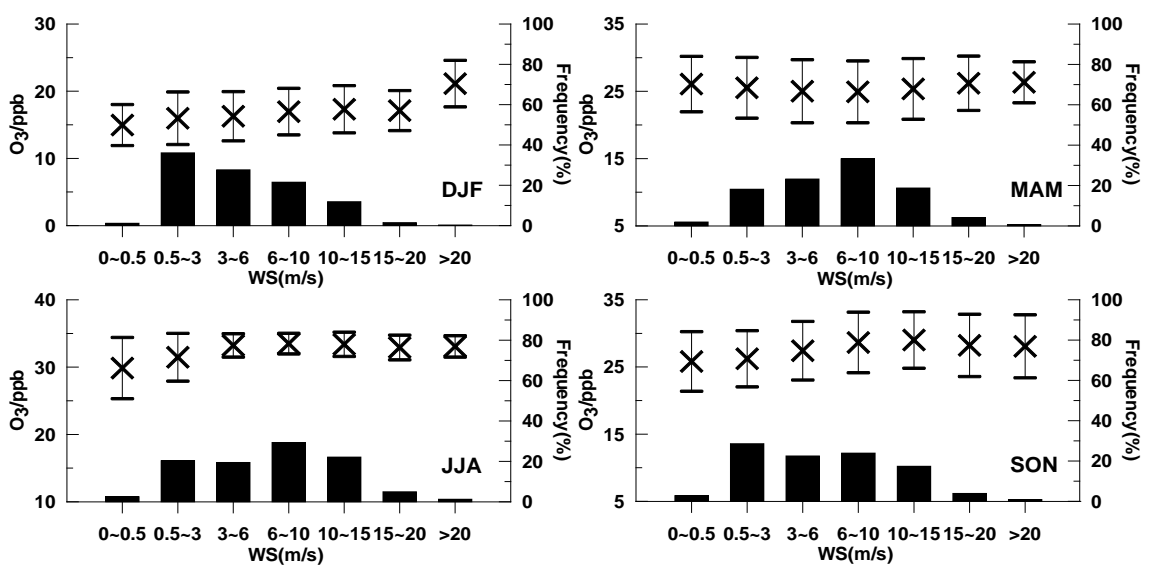

Figure 6. Occurrence frequency of different wind speed levels in four seasons and the corresponding surface ozone concentrations from 2008 to 2013 (the black frame indicates the frequency of occurrence of different wind speed levels and vertical line denotes variation range of corresponding surface ozone concentrations).

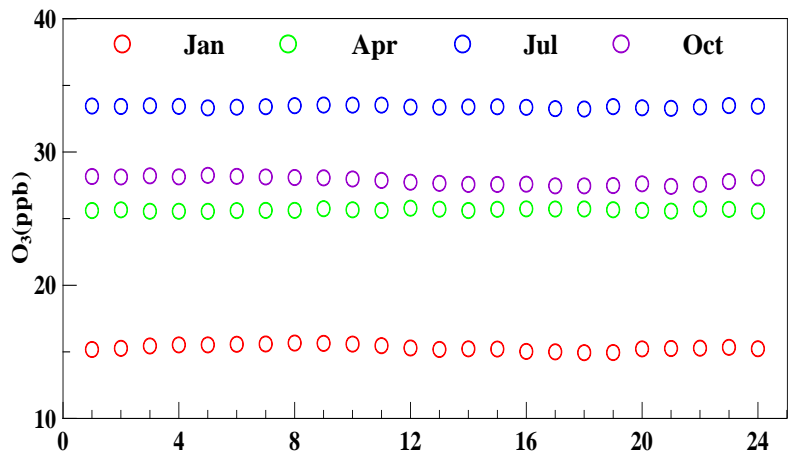

Figure 7. Average daily changes in surface ozone concentration at Zhongshan Station in January, April, July, and October.
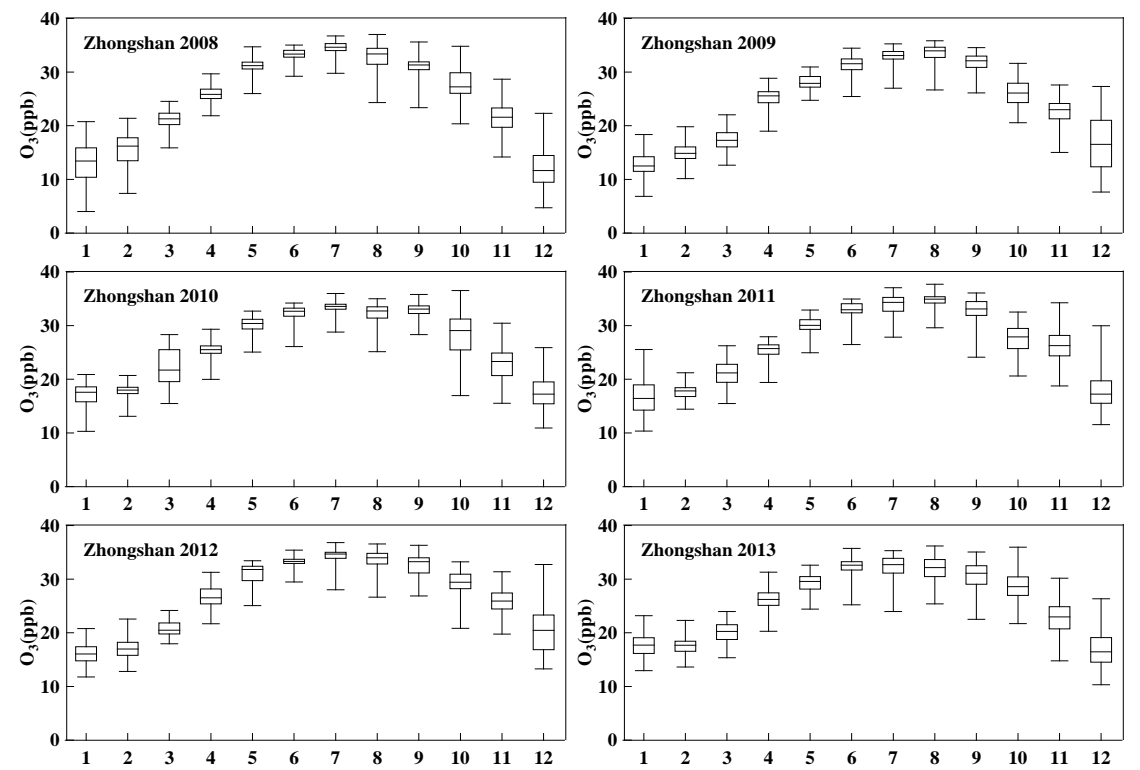

Figure 8. Boxplots of monthly surface ozone concentrations recorded by Zhongshan Station at different years from 2008 to 2013 . 
The average surface ozone concentrations and standard deviations in the spring (SON), summer (DJF), autumn (MAM), and winter (JJA) every year are listed in Table 1. In the study period, the surface ozone concentration in winter is the highest every year, followed by those in spring and autumn with small differences. By contrast, the surface ozone concentration in the summer is the lowest. Interannual changes in surface ozone concentration exist in each season, but no significant variation trend is observed.

\section{Comparison with Other Antarctic Stations}

A comparative analysis of the monthly average surface ozone concentrations at Zhongshan Station (elevation $=18.5 \mathrm{~m}$ ) with surface ozone data of other five Antarctic stations from 2008 to 2013 was conducted. Among these five stations, only South Pole Station (elevation $=2841 \mathrm{~m}$ ) is located in Antarctic inland, whereas the remaining stations (Syowa Station [elevation $=21 \mathrm{~m}$ ], Neumayer Station [elevation $=42 \mathrm{~m}$ ], Halley Station [elevation $=33 \mathrm{~m}$ ], and Arrival Heights Station [elevation $=250 \mathrm{~m}$ ]) are in coastal areas (Figure 9). A time series of the monthly average surface ozone concentrations in these six stations is

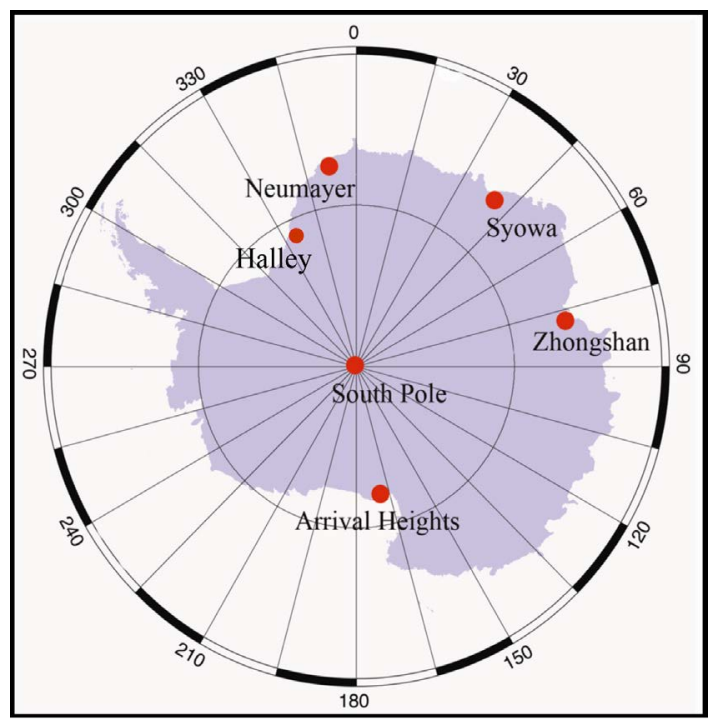

Figure 9. Distribution of surface ozone observation sites at South Pole.

Table 1. Average surface ozone concentrations and standard deviations in four seasons at the Zhongshan Station from 2008 to 2013.

\begin{tabular}{cccccc}
\hline Year & DJF & MAM & JJA & SON & Yearly \\
\hline 2008 & $13.64 \pm 3.75$ & $26.02 \pm 4.41$ & $33.05 \pm 3.54$ & $26.58 \pm 4.59$ & $24.87 \pm 8.09$ \\
2009 & $14.75 \pm 3.54$ & $22.94 \pm 5.35$ & $32.41 \pm 2.15$ & $26.81 \pm 4.29$ & $24.32 \pm 7.56$ \\
2010 & $17.49 \pm 2.97$ & $25.92 \pm 3.98$ & $32.48 \pm 2.14$ & $27.87 \pm 5.08$ & $27.07 \pm 6.08$ \\
2011 & $17.59 \pm 3.21$ & $25.53 \pm 4.11$ & $33.76 \pm 2.03$ & $28.80 \pm 3.77$ & $26.43 \pm 6.78$ \\
2012 & $18.14 \pm 3.55$ & $25.92 \pm 4.48$ & $33.62 \pm 1.75$ & $29.15 \pm 3.46$ & $26.82 \pm 6.61$ \\
2013 & $17.45 \pm 2.53$ & $24.76 \pm 4.23$ & $32.02 \pm 2.23$ & $26.66 \pm 4.77$ & $25.30 \pm 6.39$ \\
\hline
\end{tabular}


presented in Figure 10. The pattern of seasonal variation surface ozone concentrations at Zhongshan Station is similar to those in other stations. The high concentration appears in winter (JJA), and low concentration in summer (DJF). The annual amplitude of monthly average surface ozone concentrations at coastal stations was 17 - 22 ppb. In South Pole Station, the annual amplitude is close to those of other stations in winter, but is about $5 \mathrm{ppb}$ higher than those of other stations the summer. These discrepancies might be due to high elevation (2841 $\mathrm{m})$ and without transport of ocean air mass.

The interannual variations of annual average surface ozone concentrations at different Antarctic stations are similar (Table 2) ranging from $1 \mathrm{ppb}$ to $2 \mathrm{ppb}$. It indicates the small spatial differences in annual average surface ozone concentration among the different stations. The annual average surface ozone concen-
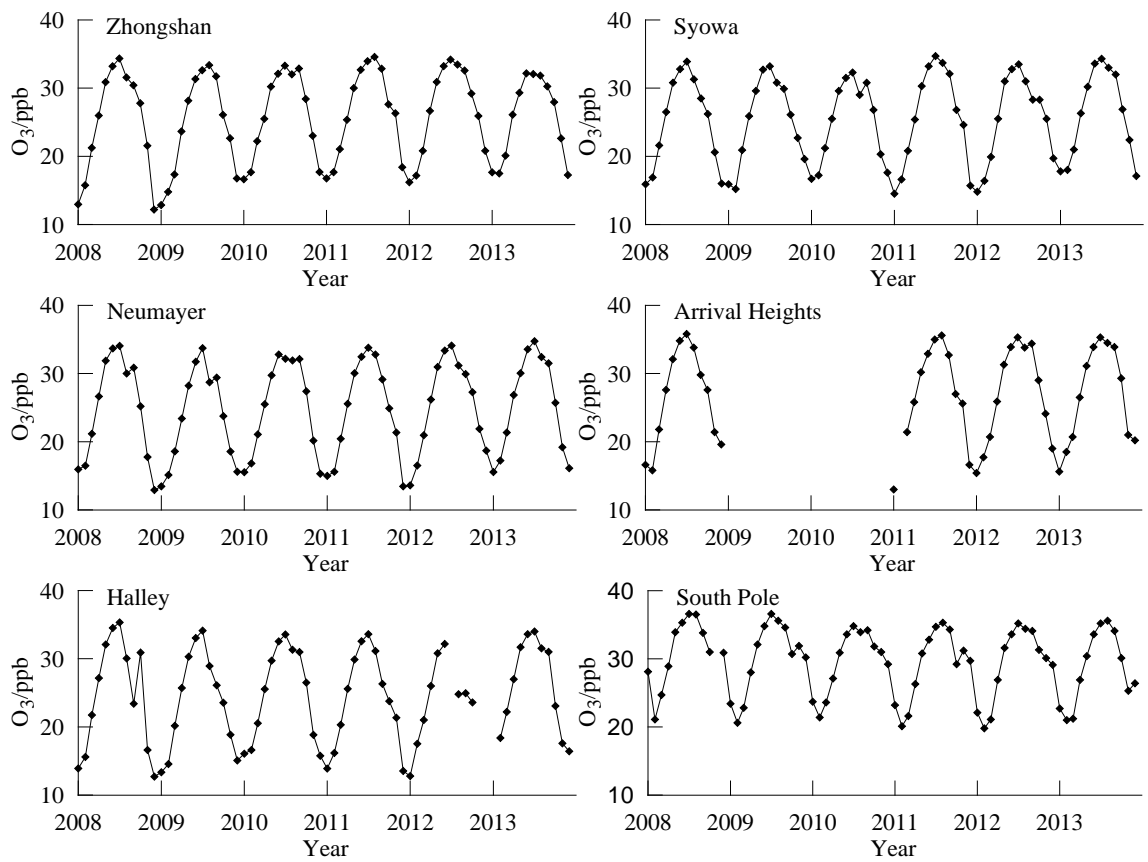

Figure 10. Time series of monthly average surface ozone concentrations at the Antarctic stations from 2008 to 2013.

Table 2. Annual average surface ozone concentrations at different observation sites from 2008 to 2013.

\begin{tabular}{ccccccc}
\hline Year & Zhongshan & Syowa & Neumayer & Halley & Arrival Heights & South Pole \\
\hline 2008 & 24.87 & 25.04 & 24.90 & 24.54 & 26.39 & 31.08 \\
2009 & 24.32 & 25.20 & 23.37 & 23.86 & - & 30.15 \\
2010 & 27.07 & 25.07 & 25.06 & 24.85 & - & 29.66 \\
2011 & 26.43 & 25.83 & 24.53 & 24.05 & 26.72 & 29.27 \\
2012 & 26.82 & 25.48 & 25.43 & 22.87 & 26.78 & 29.14 \\
2013 & 25.29 & 26.09 & 25.40 & 25.74 & 26.83 & 28.54 \\
平均 & 25.80 & 25.56 & 24.78 & 24.32 & 26.68 & 29.64 \\
\hline
\end{tabular}


tration at Zhongshan Station were $25.8 \mathrm{ppb}$, which is higher than those in Neumayer Station and Halley Station, lower than that in Arrival Heights Station, and close to that of Syowa Station. These means that measured average background concentrations of the surface ozone at Zhongshan Station are reliable.

\section{Relation between Surface Ozone and UVB}

As the cleanest region on the earth, Antarctic continent provides the smallest influence derived from human activities on the atmosphere. The concentrations of ozone precursors (e.g., $\mathrm{NO}_{\mathrm{x}}$ ) are relatively lower [2] [22]. Variations of surface ozone concentration in the Antarctic are mainly related to the UVB and photochemical reactions. Given the strong solar radiation in summer, radiation of UVB can be destroying ozone more than photochemical reaction does. This effect in relatively lower surface ozone concentration in summer is smaller than in other seasons of Antarctic region. No solar radiation is present during polar nights. Therefore, ozone concentration in winter is relatively higher than those in the other seasons.

A time series of daily average UVB and daily average surface ozone concentrations at Zhongshan Station from 2008 to 2013 as measured by the Brewer spectrometer (wavelength $=290-325 \mathrm{~nm}$ ) are shown in Figure 11. The UVB rays in summer play an important role in surface ozone production and decomposition. From March to polar nights, surface ozone concentration increases continuously while the solar radiation is gradually weakening. From the end of July to the beginning of August, that is, the beginning stage of sunrise, the ozone concentration reaches the maximum and then begins to decrease. This result is achieved because the ozone precursors accumulated during the polar nights undergoes photochemical reactions at sunrise. However, as ozone precursor reactions decrease, ozone destruction by UVB exceeds photochemical reaction. The relationship between surface ozone concentration and UVB undergoes distinct seasonal changes. The ozone is destroyed by photochemical reactions in each spring and summer. Meanwhile, the surface ozone concentration increases

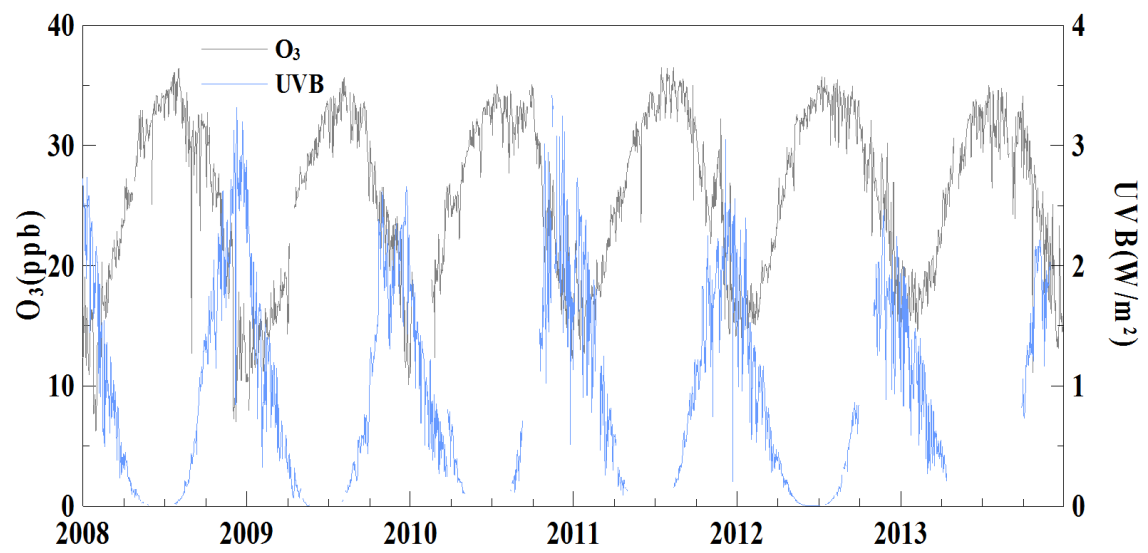

Figure 11. Time series of surface ozone $\left(\mathrm{O}_{3}\right)$ concentrations and UVB at the Zhongshan Station from 2008 to 2013. 
gradually since autumn, without ozone destruction by photochemical reactions. The relationships between UVB and surface ozone concentration in different seasons are compared in Figure 12. Surface ozone concentrations are significantly negatively correlated with UVB in the spring and autumn, with correlation coefficients of 0.50 and 0.57 under the 0.01 significance test. As a result, UVB assumes the dominant role in decomposing the surface ozone in Antarctica.

The correlation coefficient between the UVB and surface ozone concentration in summer was -0.24 (Figure 12). Although the both were negatively correlated, but the correlation coefficient was lower than those in the autumn and spring. This shows the weaker photochemical ozone destruction of UVB in summer than those in spring and autumn. The lowest surface ozone concentration and the strongest UVB occurred in summer and their relationship is relative scatter. This relation is of complicated reasons, such as increasing human activity, as well as growth in ozone production rate and cloud amount. Further related studies are needed.

\section{Conclusion}

The surface ozone observed at Zhongshan Station is only slightly affected by wind direction and speed. Local pollution from the station under westerly and calm winds accounted for only $2.1 \%$ of the total measurement period. Once this contamination is removed from the data set, the ozone observations can be used to represent the background of ozone measured on the east coast of the Antarctic continent. The average daily range of surface ozone in all four seasons is small: $0.72 \mathrm{ppb}$ (January), $0.24 \mathrm{ppb}$ (April), $0.30 \mathrm{ppb}$ (July) and $0.83 \mathrm{ppb}$ (October) respectively. The monthly mean surface ozone measured at Zhongshan station is similar to that of other stations in Antarctica, and their annual amplitudes are all within the range of $15-35 \mathrm{ppb}$ during the period 2010 - 2013. The variation ranges of the annual average surface ozone concentrations at different Antarctic stations differ by $1-2 \mathrm{ppb}$. The annual increase in recent years is no significant difference in the of surface ozone measured around the coast of the Antarctic continent showing that surface ozone observed in Antarctica has been fully mixed in the atmosphere and has not been greatly affected by local environ-
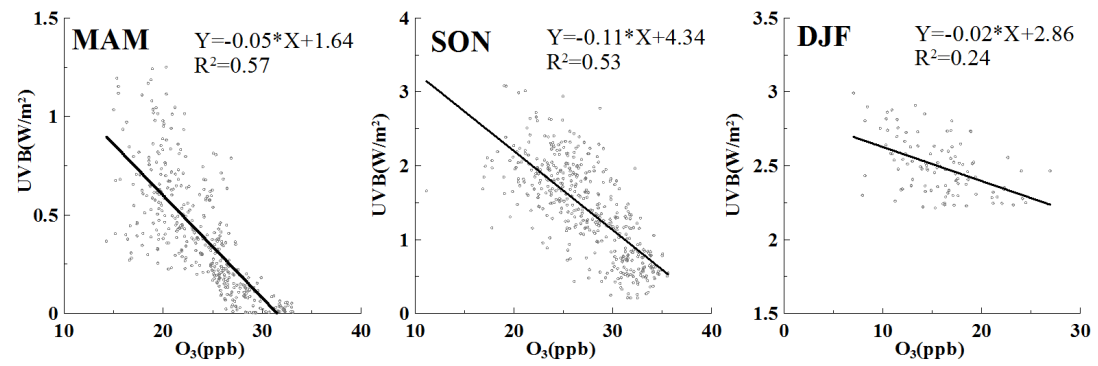

Figure 12. Relationships between the surface ozone $\left(\mathrm{O}_{3}\right)$ concentration and UVB at the Zhongshan Station in autumn (MAM), spring (SON), and summer (DJF). 
ments once obvious pollution from station activities is removed. Relationship between surface ozone concentration and UVB is significant negative correlation. This result revealed that photochemical reaction is the dominant cause of ozone destruction in Antarctica. As there is no solar radiation, surface ozone concentration during polar nights is $1-2$ times higher than that during polar days. However, there is of smallest interference from human activities in Antarctic region.

\section{Acknowledgments}

This work was supported by the Program of China Polar Environment Investigation and Assessment (Project No. CHINARE2016-2020), the authors appreciate the assistance of all staff wintered in Zhongshan station during data collection.

\section{References}

[1] Vingarzan, R. (2004) A Review of Surface Ozone Background Levels and Trends. Atmospheric Environment, 38, 3431-3442. https://doi.org/10.1016/j.atmosenv.2004.03.030

[2] Helmig, D., Oltmans, S.J., Morse, T.O., et al. (2007) What is Causing High Ozone at Summit, Greenland. Atmospheric Environment, 41, 5031-5043.

https://doi.org/10.1016/j.atmosenv.2006.05.084

[3] Ghude, S.D., Jain, S.L., Arya, B.C., et al. (2006) Temporal and Spatial Variability of Surface Ozone at Delhi and Antarctica. International Journal of Climatology, 26, 2227-2242. https://doi.org/10.1002/joc.1367

[4] Legrand, M., Preunkert, S., Jourdain, B., et al. (2009) Year-Round Record of Surface Ozone At Coastal (Dumont d'Urville) and Inland (Concordia) Sites in East Antarctica. Journal of Geophysical Research Atmospheres, 114, Article ID: D20306. https://doi.org/10.1029/2008JD011667

[5] Bauguitte, S.J.B., Brough, N., Frey, M.M., et al. (2011) A Network of Autonomous Surface Ozone Monitors in Antarctica: Technical Description and First Results. Atmospheric Measurement Techniques, 4, 645-658. https://doi.org/10.5194/amt-4-645-2011

[6] Jones, A.E., Wolff, E.W., Brough, N., et al. (2013) The Spatial Scale of Ozone Depletion Events Derived from an Autonomous Surface Ozone Network in Coastal Antarctica. Atmospheric Chemistry and Physics, 13, 1457-1467. https://doi.org/10.5194/acp-13-1457-2013

[7] Oltmans, S.J., Johnson, B.J. and Helmig, D. (2008) Episodes of High Surface-Ozone Amounts at South Pole during Summer and Their Impact on the Long-Term Surface-Ozone Variation. Atmospheric Environment, 42, 2804-2816. https://doi.org/10.1016/j.atmosenv.2007.01.020

[8] Bottenheim, J.W., Gallant, A.G. and Brice, K.A. (1986) Measurements of NOY Species and $\mathrm{O}_{3}$ at $82^{\circ} \mathrm{N}$ Latitude. Geophysical Research Letters, 13, 113-116. https://doi.org/10.1029/GL013i002p00113

[9] Kreher, K., Keys, J.G., Johnston, P.V., et al. (1996) Ground-Based Measurements of $\mathrm{OClO}$ and $\mathrm{HCl}$ in Austral Spring 1993 at Arrival Heights, Antarctica. Geophysical Research Letters, 23, 1545-1548. https://doi.org/10.1029/96GL01318

[10] Wessel, S., Aoki, S., Winkler, P., et al. (1998) Tropospheric Ozone Depletion in Po- 
lar Regions a Comparison of Observations in the Arctic and Antarctic. Tellus, 50, 34-50. https://doi.org/10.3402/tellusb.v50i1.16020

[11] Roscoe, H.K. and Roscoe, J. (2006) Polar Tropospheric Ozone Depletion Events Observed in the International Geophysical Year of 1958. Atmospheric Chemistry and Physics, 6, 3303-3314. https://doi.org/10.5194/acp-6-3303-2006

[12] Simpson, W.R., Glasow, R.V., Riedel, K., et al. (2007) Halogens and Their Role in Polar Boundary-Layer Ozone Depletion. Atmospheric Chemistry and Physics, 7, 4375-4418. https://doi.org/10.5194/acp-7-4375-2007

[13] Helmig, D., Johnson, B., Oltmans, S.J., et al. (2008) Elevated Ozone in the Boundary Layer at South Pole. Atmospheric Environment, 42, 2788-2803. https://doi.org/10.1016/j.atmosenv.2006.12.032

[14] Legrand, M., Preunkert, S., Savarino, J., et al. (2016) Inter-Annual Variability of Surface Ozone at Coastal (Dumont, d'Urville, 2004-2014) and Inland (Concordia, 2007-2014) Sites in East, Antarctica. Atmospheric Chemistry and Physics, 16, 8053-8069. https://doi.org/10.5194/acp-16-8053-2016

[15] Crawford, J.H., Davis, D.D., Chen, G., et al. (2001) Evidence for Photochemical Production of Ozone at the South Pole Surface. Geophysical Research Letters, 28, 3641-3644. https://doi.org/10.1029/2001GL013055

[16] Jones, A.E., Wolff, E.W., Brough, N., et al. (2013) The Spatial Scale of Ozone Depletion Events Derived from an Autonomous Surface Ozone Network in Coastal Antarctica. Atmospheric Chemistry and Physics, 13, 1457-1467.

https://doi.org/10.5194/acp-13-1457-2013

[17] Jones, A.E. and Wolff, E.W. (2003) An Analysis of the Oxidation Potential of the South Pole Boundary Layer and the Influence of Stratospheric Ozone Depletion. Journal of Geophysical Research Atmospheres, 108, 1399-1407. https://doi.org/10.1029/2003JD003379

[18] Sun, Y., Bian, L.G., Tang, J., et al. (2014) $\mathrm{CO}_{2}$ Monitoring and Background Mole Fraction at Zhongshan Station, Antarctica. Atmosphere, 5, 686-698. https://doi.org/10.3390/atmos5030686

[19] Bian, L.G., Gao, Z., Sun, Y., et al. (2016) $\mathrm{CH}_{4}$ Monitoring and Background Concentration at Zhongshan Station, Antarctica. Atmospheric \& Climate Sciences, 06, 135-144. https://doi.org/10.4236/acs.2016.61012

[20] Wang, C., Bian, L.G. and Ye, W.J. (2016) Background Characteristics of Atmospheric Sulfur Hexafluoride Concentrations at Zhongshan Station, Antarctica. Chinese Science Bulletin, 61, 782-790.

[21] Zhou, L.X., Wen, Y.P. and Li, J.L. (2004) Impact of Local Surface Wind on the Atmospheric $\mathrm{CH}_{4}$ Back Ground Concentration at Mt. Waliguan. Journal of Applied Meteorological Science (in Chinese), 15, 257-265.

[22] Oltmans, S.J., Lefohn, A.S. and Shadwick, D. (2012) Recent Tropospheric Ozone Changes-A Pattern Dominated by Slow or no Growth. Atmospheric Environment, 67, 331-351. https://doi.org/10.1016/j.atmosenv.2012.10.057 